\title{
Musicology: Doubts about its Subject(s) and its Pedagogical Function(s)
}

\author{
Some deeply personal remarks
}

\section{Muzikologija: Dvomi o njenem predmetu(-ih) in njeni pedagoški funkciji(-ah) Nekaj skrajno osebnih opazk}

Ključne besede: sodobna glasba, nova muzikologija, sociologija glasbe, kontekstualna analiza

POVZETEK

Avtorjeva izkušnja $\mathrm{z}$ muzikološkim raziskovanjem sodobne glasbe je razvila njegovo kritično držo do muzikologije na splošno, posebej do tiste, ki ima glasbo samo za tekst in omejuje pristope $\mathrm{h}$ glasbenemu delu na zgolj filološko metodologijo. Tako Sheringova Experimentelle Musikgeschichte (1913) kot Kermanove zahteve za muzikologijo kot zlitje znanstvenega muzikološkega dela $z$ občutkom za glasbo kot umetnost (1985) si prizadevajo, da bi se znebile tega "filološkega bremena". Nadaljnji problem je vsekakor enakovrednost vseh zvrsti glasbe, ki jih zahteva Nova muzikologija, ter nezmožnost razvijanja ustreznih analitičnih orodij za vsako od njih. Harrisonovo predlaganje etnomuzikološkega (tj. sociološkega) pristopa ni dovolj prepričljiv, ker - kot dokazuje Treitlerjev navedek - je zelo težko razbrati kontekstualni (tj. sociološki) pomen katerega koli glasbenega dela. Avtor se poteguje za zavestni kritični pristop $\mathrm{k}$ muzikološkemu raziskovanju, ki dovoljuje celo nasprotujoča branja istega teksta in opozarja, da je to način, s katerim prepriča
Keywords: contemporary music, new musicology, sociology of music, contextual analysis

SUMMARY

The author's experience with musicological research of contemporary music developed his critical attitude towards musicology in general, especially towards the one that considers music only as text and limits the approaches to musical works on philological methodology. Both Schering's Experimentelle Musikgeschichte (1913) and Kerman's requests for musicology as fusion of scholarly musicological work and sense for music as art (1985) attempt to get rid of this "philological burden". A further problem, however, is the equality of all kinds of music, requested by the New musicology and the impossibility to develop appropriate analytical tools for each of them. Harrison's suggestion of ethnomusicological (i.e. sociological) approach is not sufficiently convincing, because - as proven by the quotation from Treitler - the contextual (i.e. social) meaning of any musical work is not so easily to decipher. The author pleads for consciously critical approach to musicological research which permits even contrary readings of the same text, and 
svoje študente, da obvladujejo praznine v poznavanju njihovega subjekta zanimanja. points out that this is the way in which he persuades his students to cope with the lacunae of their subjects of interest.

These remarks are deeply personal at a purely (auto)biographical level. Although this might bother you, it seems to me that this is nevertheless the right time and place to remind of them: Namely, I obtained my BA and PhD degree at this Department, indeed with the papers dedicated entirely to contemporary music - I would say, a rather rare case in musicology. However there was no unwillingness at the Department to accept these topics which I proposed myself and which were in both cases sincerely supported by my mentor, Prof. Andrej Rijavec. I came to study musicology in Ljubljana after I had obtained a BA degree in comparative literature at the University in Zagreb. That is, I already had some kind of critical feeling toward any kind of scientific approach to the arts in general, especially toward the ambitions of this approach to prescribe and to dictate how the arts should behave. (My BA paper in Zagreb dealt with music critiques of Bernard Shaw.) I had no special inclination toward contemporary music but the musicology I got acquainted with during my studies in Ljubljana seemed to me even more prescriptive than the literary theory I become acquainted with during my studies of comparative literature in Zagreb. I thought therefore that one of the raisons d'être for musicology in general should be its conntact with live, i.e. contemporary music because its stressed interest toward the music of the past, especially toward the music hidden in the dusty boxes, did more harm than benefit to this music. At least, nobody needs musicology to enjoy music! I admit, it is rather strange to have such an attitude toward a scientific discipline that one pretends to accept as one's professional vocation. But this attitude which was only critical but not negative - was first of all supported by my mentor in Ljubljana and further on by the delicate sense for relativization of Carl Dahlhaus (with whom I had the honour to work for shorter time in Berlin during the preparation of my $\mathrm{PhD}$ paper) and by the cynical relationship toward so-called "scientific truth" in musicology of Hans Heinrich Eggebrecht (with whom I had the honour to work and to discuss various interesting matters many times).

Although I was brought up in the tradition of German musicology (one might ask which other musicological tradition exists at all, but this important question is not the matter of my interest now!), what bothered (and still bothers) me was just the relationship of this tradition toward music as an art. This shows quiet clearly the relationship of this (but also of any other) musicology toward contemporaneity, i.e. toward contemporary music. Although Guido Adler in 1885 believed that "[t]he theorist of art ... serves as life companion to the inspired creative artist" (Adler 1988: 351), he nevertheless in fact imagined this service as a kind of theorist's (i.e. musicologist's) control over creative artists. The musicology that Adler founded was primarily historical and this meant that the contemporaneity could not be its matter of interest because of apparently non-existent historical distance as the faked proof of so-called objectivity. Certainly no history of music is imaginable without musicological research, but the question is what is music in the history of music. It is bound with the concept 
of work as text and is therefore primarily the matter of philological research. Philipp Spitta, well-known because of his pioneering work on Bach in late $19^{\text {th }}$ century, was educated as a classical philologist. Joseph Kerman is fully aware of this "philological burden" that musicology obviously cannot avoid in its relationship to music as art and he hopes for musicology as fusion of scholarly philological work and sense for music as art: "There is a widely held conviction that musicologists are, if not actually failed musicians, then at any rate persons of sharply limited musical sensibility persons who know a lot of facts about music and very little about 'the music itself'. That could be true of certain musicologists. But with the majority of them, in my experience, it is not so much a matter of inherent musicality as of a deliberate policy of separating off their musical insights and passions from their scholarly work. I believe this is a great mistake; musicologists should exert themselves towards fusion, not separation." (Kerman 1985: 18-19). And Arnold Schering (1912-1913) sketched in 1913 his Experimentelle Musikgeschichte with the request that the scholary, scientific "paper" research should obligatorily be connected with the practical verification of their results.

Nobody can complain about these demands! But the question (on which I still have no answer) is how to realize it through the curricula of our teaching classes. Some solutions can be envisaged (at least at the level of histories of music in sound) if we restrict ourselves to the so-called art music. But the postmodern idea about the equality of all kinds of music (which makes it necessary to speak about music in the plural - i.e. about musics!) confronts us with the problem of appropriate scientific methods for approaching them. Due to the lack of time it is absolutely impossible even to mention all the musics (if it is done, then in most cases from the point of view of the teacher's preferences), not to mention all the methods for the approach to their individual research. I have also noted in last five or six generations which have passed through my classes that the students have been far less interested in art music (which is, of course, supposed to be the main subject of studies) then in more popular contemporary musical phenomena like new age music, techno, hip hop, ethnic musics, extra-European folklore etc. As I have never felt competent to soothe these kinds of interest, my ethnomusicological colleagues had to take the responsibility. This reminds us again of the well-known anthropological issue about "the history of music as an aspect of the history of man in society" (Harrison 1963: 79) that caused Frank Ll. Harrison to claim that "the function of all musicology [is] to be in fact ethnomusicology, that is, to take its range of research to include material that is termed 'sociological'" (Harrison 1963: 80). As we shall try to suggest later, the issue of sociology (of music) makes the core of contextuality of music in so-called New Musicology.

With the emergence of New Musicology our position was rather paradoxical: The backbone of our curricula is primarily formed around German musicological tradition. And the idea (or even ideology) of New Musicology, which cannot be ignored if we want the students to be properly informed about most recent streams, is frequently opposed just to this German musicological tradition. Our students are in fact situated between two traditions (or "schools") which they tend to conceive as opposed as if the one excludes the other. If we add to this supposed opposition between 
traditions (or "schools") further the distinction between theory, analysis, criticism, music history and musicology in the British-American area, which does not exist in Continental Europe, the problem becomes unsolvable. What are actually the real disciplines of musicology with which the students have to get acquainted with during eight semesters of their studies? We can only yearningly look at Adler's "tabular survey" at the end of his above mentioned article from 1885 (Adler 1988: 354-355) (in spite of some unexcusable mistakes in its English translation).

New Musicology clearly opposes the German concept by negating the musical work as an autonomous entity; instead it should be regarded as a part of the "social context" (Harrison 1963: 80), i. e. the musicology should become contextual. Lawrence Kramer considers it as the condition that has to be fulfilled by the "postmodernist musicologies": "The emergence of postmodernist musicologies will depend on our willingness and ability to read as inscribed within the immediacy-effects of music itself the kind of mediating structures usually positioned outside music under the rubric of context." (Kramer 1995: 18) But that what is "positioned outside music under the rubric of context" reminds us so strongly of Adornos "deciphering of social content of music" (Adorno 1998; Adorno 1998a) which Tibor Kneif understands as "an esoteric secret skill" which should also be the subject of the semiotics of music (Kneif 1990: 141), especially regarding the shift of the composer's interest from beautiful to truthful, because this shift represents the clear sign of contextual negation of the primacy of aesthetic autonomy of musical works. In other words the deciphering of this context is nothing explicitly new, neither in the sense of "postmodernist musicologies" or New Musicology in general. Leo Treitler points out to the fact that the work of art cannot bear the dynamism of social context and in fact escapes the possibilities of its analytical deciphering: " "... the question arises... about the participation of music in the society or the culture in the sense of the interpretations, and it is perhaps the most important question. Has the case really been made that the mirror relationship of the harmony of Estrella and Chiarina represents 'a concrete effort to affect the culture amid which it is produced and received', as Kramer puts it? If music is to be understood, as McClary proposes, as 'social discourse', was anyone listening to the slow movement of K. 453 in that sense? No evidence or even suggestion is offered to that effect by either author. That is what makes these proposals seem precariously close to interpretations that are driven by little more than the need to make them. In both cases what is being proposed is not really a picture of music interacting with society or culture of its time, but another way of reading musical works which, like so many blotters, have soaked up the conditions of their time but which, as we read them, are nevertheless considered in their autonomy, as inert records." (Treitler 1999: 369-370)

How can I then convince anybody, especially my students, that the emergence of contextuality in musicology is the right way of its salvation and that the concept of autonomous musical work is just a fallacy?

1 Treitler refers to Kramer 1993 and McClary 1986. 
However, my educational doubts do not relate primarily to the choice of disciplines, that is to the methods corresponding to them. I want my students to think critically about musicology from the very beginning. They must - also from the very beginning - be aware of the dialectics of scholary discourse, of functioning of the hermeneutic spiral, i.e. of the necessity of various coexisting interpretations of the same content or about the possibility of even contrary readings of the same texts. The positive achievements should prove that the lacunae of their scientific discipline are always positive stimuli for still deeper discourse. Fortunately enough, I have in a number of cases succeeded to direct them toward these incommensurable depths.

\section{Literature}

Adler, Guido, 1988. "The Scope, Method and Aim of Musicology" (transl. by Martin Cooper). In: BUJIC, Bojan (ed.). Music in European Thought 1851-1912. Cambridge: Cambridge University Press. 348-355.

Adorno, Theodor W., 1998. Einleitung in die Musiksoziologie. Zwölf theoretische Vorlesungen (= Gesammelte Schriften, vol. 14). Darmstadt: Wissenschaftliche Buchgesellschaft. 169-447 (especially 422-433).

Adorno, Theodor W., 1998a. "Zur gesellschaftlichen Lage der Musik". In: Musikalische Schriften $V(=$ Gesammelte Schriften, vol. 18). Darmstadt: Wissenschaftliche Buchgesellschaft. 729-777.

Harrison, Frank Ll, 1963. "American Musicology and European Tradition". In: Harrison, Frank Ll. - Hood, Mantle - Palisca, Claude V. (eds.). Musicology. Englewood Cliffs (NJ): Prentice-Hall. 1-85.

Kerman, Joseph, 1985. Musicology. London: Fontana Press/Collins.

Kneif, Tibor, 1990. "Musik und Zeichen. Aspekte einer nichtvorhandenen musikalischen Semiotik". In: Karbusicky, Vladimir (ed.). Sinn und Bedeutung in der Musik. Darmstadt: Wissenschaftliche Buchgesellschaft. 134-141.

Kramer, Lawrence, 1993, "Carnaval, Cross-Dressing, and the Woman in the Mirror". In: Solie, Ruth A. (ed.). Musicology and Difference. Gender and Sexuality in Music Scholarship. Berkeley: University of California Press. 305-325.

Kramer, Lawrence, 1995, "Prospects. Postmodernism and Musicology". In: Classical Music and Postmodern Knowledge. Berkeley: University of California Press. 1-32.

McClary, Susan, 1986, "A Musical Dialectic from the Enlightenment: Mozart's Piano Concerto in G Major, K. 453, Movement 2“. Cultural Critique. 4. 129-169.

Schering Arnold, 1912-1913, "Experimentelle Musikgeschichte". Zeitschrift der internationalen Musikgesellschaft. 14. 234-240.

Treitler, Leo, 1999, "The Historiography of Music: Issues of Past and Present". In: Cook, Nicholas - Everist, Mark (eds.). Rethinking Music. Oxford: Oxford University Press. 356-377. 